\title{
Galectin-3 Modulates Experimental Colitis
}

\author{
Elisabeth Lippert Manuela Stieber-Gunckel Nadja Dunger Werner Falk \\ Florian Obermeier Claudia Kunst
}

Department of Internal Medicine I, University Hospital Regensburg, Regensburg, Germany

\section{Key Words}

Colitis · Crohn's disease · Inflammation · Inflammatory bowel disease - Ulcerative colitis · Galectin-3

\begin{abstract}
Background: We recently identified galectin-3 (gal-3) as a new and strong fibroblast activator produced by colonic epithelial cells. Very little is known about the influence of gal-3 in inflammatory bowel disease. We, therefore, investigated the impact of gal-3 on dextran sodium sulfate (DSS)-induced colitis in a mouse model. Methods: Colonic lamina propria fibroblasts of healthy controls were used for co-incubation studies of gal-3 with gal-1, TGF- $\beta 1$, IFN $\gamma$, IL-4 and IL-10. Acute and chronic DSS colitis was induced by $3 \%$ DSS in drinking water in female Balb/c mice weighing 20-22 g. Recombinant gal-3 was expressed by the pET vector system and used for a 5-day treatment in different concentrations intraperitoneally. The distal third of the colon was used for histologic analysis. Colonic cytokine expression was determined by quantitative RT-PCR. Results: In vitro, gal-3 induced IL-8 secretion was significantly reduced by co-incubation with IL-10 $(5 \mathrm{ng} / \mathrm{ml})$ and IL-4 (10 ng/ml). Acute DSS-induced colitis was ameliorated by gal-3 treatment as indicated by increased colonic length and reduced weight loss compared to that of controls. In acute and chronic colitis, gal-3 treatment resulted in a significant suppression of colonic IL-6. Conclusion: Gal-3 significantly reduces inflammation in acute and chronic DSS colitis in mice indicating a potential role in intestinal inflammation.
\end{abstract}

(c) 2015 S. Karger AG, Basel
(C) 2015 S. Karger AG, Basel

0012-2823/15/0921-0045\$39.50/0

\section{Introduction}

We recently identified galectin-3 (gal-3) as a colonic lamina propria fibroblast (CLPF)-activating factor produced by colonic epithelial cells (CECs) [1]. Supernatants of cultured primary human CECs strongly activated CLPF or the intestinal fibroblasts cell line CCD-18Co indicated by increased NF- $\mathrm{\kappa B}$ activation and IL- 8 secretion. By a classical biochemical approach, we isolated the major protein of the activating fast protein liquid chromatography fractions from the CEC supernatants, and it was consecutively identified to be gal-3. Stimulation of CLPF with recombinant gal-3 resulted in a strong increase of CLPF IL-8 secretion. In further analysis, we demonstrated a downregulation of gal-3 in CLPF from Crohn's disease (CD) fistulae and stenosis and macrophages of CD patients indicating a key role in inflammatory bowel disease (IBD) and mucosal inflammation [2].

Gal-3 belongs to the group of $\beta$-galactoside-binding proteins with 14 mammalian members known [3]. Three subgroups [4] of galectins are differentiated upon their structures and sequences (prototype group, tandem repeat group and chimera group). Each galectin contains a unique domain of 130 amino acids which is responsible for the carbohydrate-binding activity, the so-called 'Carbohydrate Recognition Domain' (CRD) [4, 5]. Gal-3 is the only member of the so-called 'chimera group' with an unusual prolin- and glycine-rich N-terminal domain attached to the C-terminal CRD domain. The N-terminal

\section{KARGER 125}

E-Mail karger@karger.com www.karger.com/dig
Elisabeth Lippert, MD

Department of Internal Medicine I

University of Regensburg

DE-93042 Regensburg (Germany)

E-Mail elisabeth.lippert@ @linik.uni-regensburg.de 
was shown to lack carbohydrate-binding activity, but is essential for the full biological activity of gal-3 [5]. Furthermore, the $\mathrm{N}$-terminal domain has been implicated in the secretion of gal-3 [6]. The C-terminal domain includes a sugar-binding site known to be blocked by lactose $[5,7]$. Galectins are expressed by a variety of cell types and are present both intracellularly and extracellularly in a large number of tissues and cell types such as epithelial cells, fibroblasts, keratinocytes, osteoclasts, Langerhans cells, dendritic cells, monocytes and macrophages [8-12].

The function of gal-3 self is pleiotropic including cell proliferation, adhesion and survival [13-16]. Galectins can modulate processes such as apoptosis, cytokine secretion, cell adhesion and migration [17] and are implicated in the regulation, activation, differentiation and survival of T-cells, playing critical roles in the modulation of chronic inflammatory disorders such as IBDs and other autoimmune diseases $[18,19]$.

Gal-3 itself protects against the formation of reactive oxygen products [20]. Gal-3-transfected T-cells showed higher and faster growth rates compared to controls. It plays a role in wound healing and accelerating re-epithelialization [21]. Gal-3-deficient mice developed less inflammatory cell infiltrates in the peritoneal cavity after thioglycollate instillation compared to control mice [22].

These known functions and our observation that gal-3 is a major activator of CLPF secreted by CECs is promising to further investigate its role in the intestinal immune system and the pathophysiology of IBD.

So far the potential involvement of gal-3 in IBD pathophysiology has not been investigated into greater detail. We further investigated the influence of gal-3 on the intestinal immune functions under physiologic conditions and its potential role in IBD.

\section{Materials and Methods}

\section{CLPF Stimulation}

Human CLPF of healthy controls $(n=3-5)$ were isolated and cultured as described previously [1]. Mucosa from surgical specimens was cut into 1-mm pieces, whereas biopsy specimens were used directly for the isolation of CLPF. Epithelial cells were separated in Hank's balanced salt solution without $\mathrm{Ca}^{2+}$ and $\mathrm{Mg}^{2+}$ (PAA Laboratories GmbH, Linz, Austria) with 2 mM EDTA (Sigma, Deisenhofen, Germany). The remaining tissue was rinsed and digested for $30 \mathrm{~min}$ at $37^{\circ} \mathrm{C}$ with $1 \mathrm{mg} / \mathrm{ml}$ collagenase 1 (Sigma), $0.3 \mathrm{mg} / \mathrm{ml}$ DNase I (Boehringer Ingelheim, Ingelheim, Germany) and $2 \mathrm{mg} / \mathrm{ml}$ hyaluronidase (Sigma) in PBS (Gibco, Karlsruhe, Germany). Isolated cells were cultured in $25 \mathrm{~cm}^{2}$ cell culture flasks (Costar, Bodenheim, Germany) with Dulbecco's modified Eagle's medium (DMEM) containing 10\% FCS, penicillin (PAA Laboratories), streptomycin $10 \mathrm{mg} / \mathrm{ml}$ (PAA Laboratories), ciprofloxacin $2 \mathrm{mg} / \mathrm{ml}$ (Bayer, Leverkusen, Germany), gentamycin $50 \mathrm{mg} / \mathrm{ml}$ (PAA Laboratories) and amphotericin B $1 \mathrm{mg} / \mathrm{ml}$ (Biochrom, Berlin, Germany). Non-adherent cells were removed by subsequent changes of medium. The remaining cell culture contained CLPF and was used between passages 3 and 8 . The study was approved by the University of Regensburg Ethics Committee.

\section{Galectins}

Recombinant human gal-1 and gal-2 were purchased by R\&D Systems, Wiesbaden, Germany.

Recombinant Gal-3. HT-29 cells were obtained from the European Collection of Cell Culture and cultured in DMEM (PAA Laboratories) supplemented with 10\% FCS (Pan Biotech, Aidenbach, Germany), $1 \%$ sodium pyruvate (PAA Laboratories), 1\% non-essential amino acids (PAA Laboratories) and $1 \%$ penicillin/ streptomycin under standard tissue culture conditions. Cells were cultured at $37^{\circ} \mathrm{C}$ in a $10 \% \mathrm{CO}_{2}$ atmosphere. Gal-3 was generated from HT-29 cells, and recombinant gal-3 was produced using the pET-vector systems followed by avidin chromatography purification (primer $5^{\prime}$-CGGATCCAATGGCAGACAATTTTTC- ${ }^{\prime}$ and 5'-CCAAGCTTTTTATATCATGGTATATGAAGC-3').

\section{Enzyme-Linked Immunosorbent Assay}

IL-8 ELISA was performed according to the manufacturer's protocol (Biozol, Echingen, Germany).

Mice

Female BALB/c mice weighing 20-22 g (Charles River, Sulzfeld, Germany) were used for the experiments and housed in a conventional facility. Animal studies were approved by the review board of the regional authority ('Regierung der Oberpfalz').

\section{Acute and Chronic Colitis}

Dextran sodium sulfate (DSS) was purchased from ICN (Mr 37,000-50,000, Eschwege, Germany). The induction of acute colitis was achieved by administering $3 \%$ DSS in the drinking water ad libitum for 7 days. For induction of chronic colitis, BALB/c mice received 4 cycles of DSS treatment. Each cycle consisted of $3 \%$ DSS in drinking water for 7 days, followed by a 10-day interval with normal drinking water. In contrast to the self-limited inflammation in acute DSS colitis, which is induced by only 1 cycle of DSS feeding, chronic DSS-induced colitis is characterized by a self-perpetuating chronic inflammation, which lasts for several months. Four weeks after the induction phase, as well as in acute colitis, mice were treated with gal-3 in different concentrations dissolved in $100 \mu \mathrm{l}$ PBS or PBS alone ( $100 \mu \mathrm{l}$, control) intraperitoneally (i.p.) daily for 5 days or day 3 to day 7. Mice used for experiments were age matched and had received DSS treatment simultaneously.

\section{Measurement of Myeloperoxidase Activity}

Colonic myeloperoxidase (MPO) activity was determined using a modified standard method. Briefly, colonic tissue was homogenized in $1 \mathrm{ml}$ of $50 \mathrm{mmol} / \mathrm{l}$ potassium phosphate buffer of $\mathrm{pH}$ 6.0 containing $0.5 \%(\mathrm{w} / \mathrm{v})$ hexadecyltrimethylammonium hydroxide, and it centrifuged at $20,000 \mathrm{~g}$ at $4^{\circ} \mathrm{C}$ for $20 \mathrm{~min}$. Supernatant $(10 \mu \mathrm{l})$ was transferred into the phosphate buffer of $\mathrm{pH} 6.0$ contain-

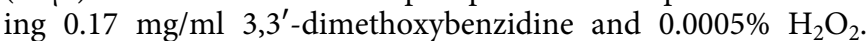
MPO activity of the supernatant was determined by measuring the 
$\mathrm{H}_{2} \mathrm{O}_{2}$-dependent oxidation of $3,3^{\prime}$-dimethoxybenzidine and expressed as units per gram of total protein. Total protein content of the samples was analyzed using a bicinchoninic acid protein assay kit (Sigma, Germany).

\section{Assessment of Histological Score}

The distal third of the colon was removed and used for histological analysis as described before [23]. Cross-sections of the colon were fixed in $10 \%$ buffered formalin and stained with hematoxylin-eosin. To quantify the histological damage in intestinal tissue, a previously described scoring system was applied [24]. Histological analysis was performed by 2 investigators in a blinded fashion.

\section{Polymerase Chain Reaction}

cDNA were synthesized from $1 \mu \mathrm{g}$ total RNA using $2.5 \mu \mathrm{M}$ poly $(\mathrm{dT}), 12.5 \mathrm{U}$ AMV reverse transcriptase, $0.5 \mathrm{mM}$ of each dNTP, $5 \mathrm{mM} \mathrm{MgCl}_{2}$ and $32 \mathrm{U}$ RNase inhibitor in a final volume of $20 \mu \mathrm{l}$ (all reagents from Amersham, Biosciences). PCR was performed for 40 cycles $\left(0.5 \mathrm{~min}\right.$ at $95^{\circ} \mathrm{C}, 0.5 \mathrm{~min}$ at $55^{\circ} \mathrm{C}, 0.5 \mathrm{~min}$ at $72^{\circ} \mathrm{C}$ ) in a volume of $40 \mu \mathrm{l}$. The reaction mixture contained $10 \mathrm{mM}$ Tris, pH 8.3, $50 \mathrm{~mm} \mathrm{KCl,} 2 \mathrm{~mm} \mathrm{MgCl} 2,400 \mu \mathrm{M}$ of each dNTP, $1 \mathrm{U}$ Taq DNA polymerase (all from Amersham Biosciences). Primers (TipMolBiol, Berlin, Germany) were added to a final concentration of 250 nM: TNFa: $5^{\prime}$-GGC AGG TCT ACT TTG GAG TCA TTG C- $3^{\prime}$ and $5^{\prime}$-ACA TTC GAG GCT CCA GTG AAT TCG G-3'; IL-10: $5^{\prime}$-TCC TTA ATG CAG GAC TTT AAG GGT TAC TTG- ${ }^{\prime}$ and $5^{\prime}$-GAC ACC TTG GTC TTG GAG CTT ATT AAA ATC- ${ }^{\prime}$; IL-6: 5' ${ }^{\prime}$ TGGACTCACAGAAGGAGTGGCTAA- $3^{\prime}$ and $5^{\prime}$-TCTG ACCACAGTGAGGAATCTCCAC-3'.

\section{Lymph Node Preparation}

Mesenteric lymph nodes (MLNs; pooled from each group of mice) were collected under sterile conditions in cold cell culture medium (RPMI 1640, 10\% FCS, $100 \mathrm{U} / \mathrm{ml}$ penicillin and $100 \mu \mathrm{g} /$ $\mathrm{ml}$ streptomycin from GIBCO-BRL (Eggenstein, Germany) and $3 \times 10^{-5}$ M 2-mercaptoethanol (Sigma, Deisenhofen, Germany)). Lymph nodes were mechanically disrupted and filtered through a cell strainer $(70 \mu \mathrm{m})$. Cells $\left(2 \times 10^{5} /\right.$ well $)$ were incubated in $200 \mu \mathrm{l}$ culture medium for $24 \mathrm{~h}$, and spontaneous cytokine secretion into the supernatants was measured by ELISA (all from Endogene, Woburne, Mass., USA), using 4 wells per condition.

\section{Statistics}

Statistical analysis was performed using the Mann-Whitney rank sum test or one-way analysis of variance with Bonferroni correction for more than 2 groups. Measured values are expressed as median \pm 5 th/95th percentile. Statistically significant differences were accepted when $\mathrm{p}$ value was less than 0.05 .

\section{Results}

\section{IL-10 and IL-4 Reduce Gal-3-Induced IL-8 Secretion While TGF- $\beta 1$ Increases Gal-3-Induced IL-8}

To evaluate if further proteins are additionally involved in the previously described pro-inflammatory effect of gal-3 in vitro, we performed co-incubation studies

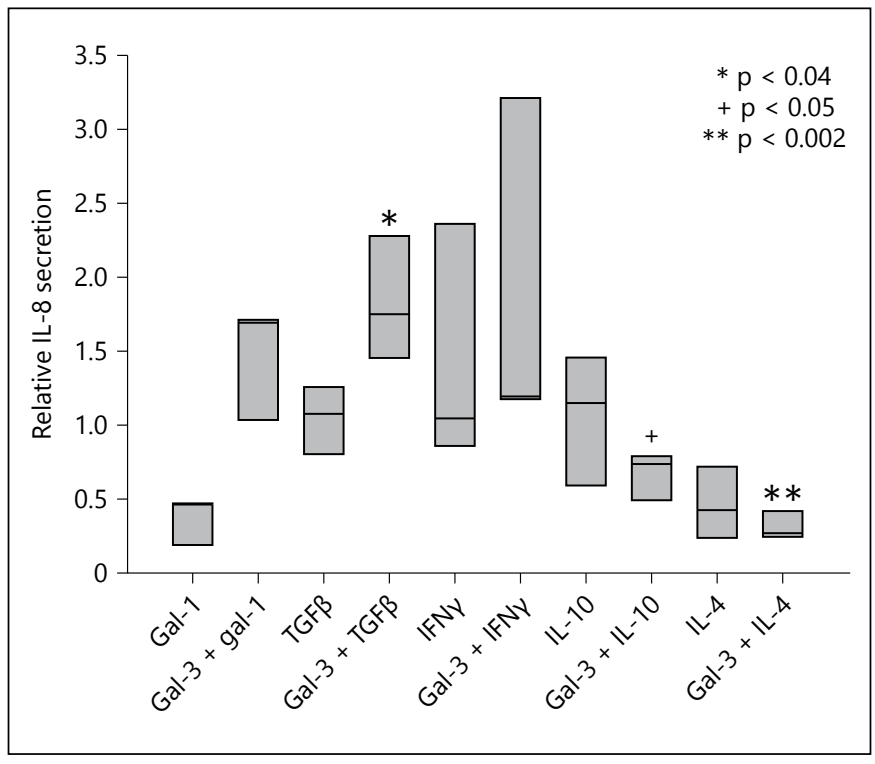

Fig. 1. IL-10 and IL-4 reduce gal-3 induced proinflammatory IL-8 secretion. CLPFs were incubated with gal-3 \pm gal-1 or gal- 2 and TGF- $\beta 1$, IFN $\gamma$, IL- 4 and IL-10 in different concentrations for $24 \mathrm{~h}$. IL- 8 was assessed in the supernatant of the cells. Data are given relatively to gal-3, $\mathrm{n}=3-5$. Gal- 3 coincubated with TGF- $\beta 1$ reached statistical significance $(\mathrm{p}<0.04)$, besides IL-10 $(\mathrm{p}<0.05)$ and IL-4 $(\mathrm{p}<$ 0.002 ) co-incubation with gal-3 significantly reduced IL- 8 secretion.

of gal-3 with different pro- and anti-inflammatory cytokines and other galectins.

CLPF of healthy controls were incubated with gal-3 \pm gal-1 $(10 \mu \mathrm{g} / \mathrm{ml})$ or gal-2 $(10 \mu \mathrm{g} / \mathrm{ml})$ and pro- and antiinflammatory cytokines (TGF- $\beta 1(1 \mathrm{ng} / \mathrm{ml}), \mathrm{IFN} \gamma(1 \mathrm{ng} /$ $\mathrm{ml})$, IL-4 (10 $\mathrm{ng} / \mathrm{ml})$ and IL-10 $(5 \mathrm{ng} / \mathrm{ml}))$ in different concentrations for $24 \mathrm{~h}$. Subsequently, IL-8 secretion as a readout for cell activation was quantified in the supernatants of the cells by ELISA (fig. 1). Data are given relatively for stimulation with gal-3 alone.

As demonstrated [1], gal-3 dose-dependently induced IL- 8 secretion of CLPF. Co-incubation of gal- 3 and gal-1 resulted in a concentration-dependent increase of IL-8 secretion (fig. 1; no statistical significance), while gal-2 did not further increase gal-3-induced IL-8 secretion (data not shown). Stimulation with gal-3 and TGF- $\beta 1$ had a synergistic effect on IL-8 secretion reaching statistical significance compared to gal-3 alone (fig. $1 ; \mathrm{p}<0.04$ ), while IFN $\gamma$ had no significant additional effect on proinflammatory IL-8 secretion of gal-3 (fig. 1). However, IL-10 ( $<$ < 0.05) and IL-4 ( $<$ < 0.002) co-incubation with gal-3 significantly reduced IL-8 secretion by CLPF (fig. 1 ).

While the IL- 8 inducing effect of gal- 3 was augmented by cytokines such as TGF- $\beta 1$ - a protein with pleiotropic 
Fig. 2. Gal-3 reduces inflammation in acute colitis. a Gal-3 treated mice showed increased colon length ( $\mathrm{p}<0.009$ with gal-3 $50 \mu \mathrm{g} / \mathrm{ml})$. b Gal-3 treated mice had less weight loss compared to control mice (statistical significance at day 7 for gal-3 $1 \mu \mathrm{g} /$ $\mathrm{ml}$ and gal-3 $0.1 \mu \mathrm{g} / \mathrm{ml}$ treated mice compared to control, $\mathrm{p}<0.001$ for both groups).

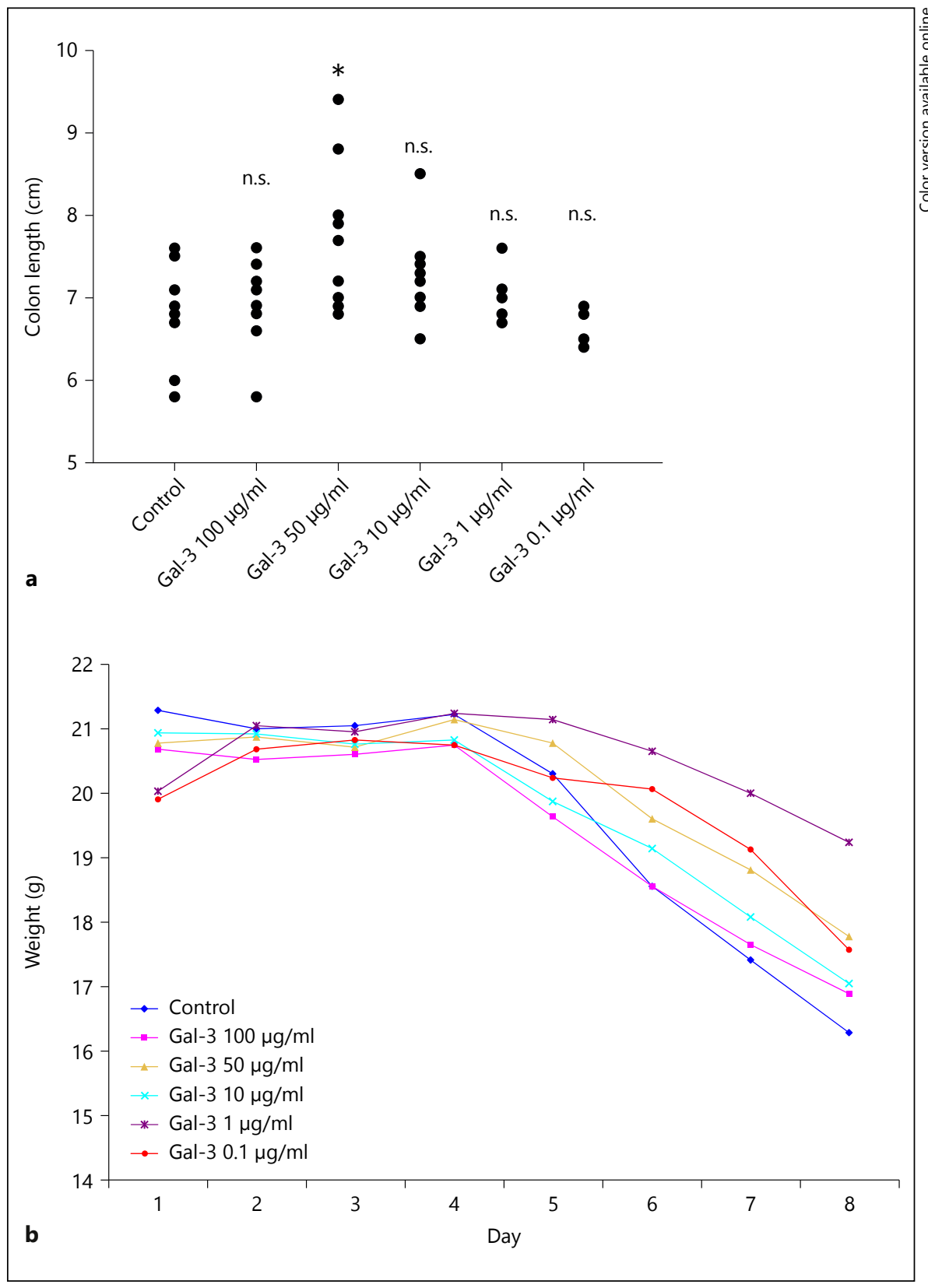

functions such as cell growth, wound healing or immune regulation - we could clearly show the cytokines such as IL-4 and IL-10, both known to have a protective role in colitis in vivo, can antagonize the IL-8 inducing effect of gal-3 into a more balanced direction in vitro.

\section{Gal-3 Reduces Inflammation in Acute DSS-Induced}

Colitis in Mice

To further assess the effect of gal-3 in intestinal inflammation in vivo, we investigated the role of gal-3 in a mouse model of acute DSS-induced colitis. Gal-3 was applied i.p. in different concentrations $(100,50,10,1$ and $0.1 \mu \mathrm{g} / \mathrm{ml}$ ), while PBS i.p. was used as control. Reduction of the colon length caused by the infiltration of inflammatory cells is a well-known feature of DSS colitis [25]. Colon length was significantly increased in gal-3-treated mice compared to controls in a concentration-dependent manner (fig. 2a). Mice were monitored for clinical signs of colitis and differences in the course of weight loss. Weight loss was lower in gal-3-treated mice (gal-3 $1 \mu \mathrm{g}$ / 


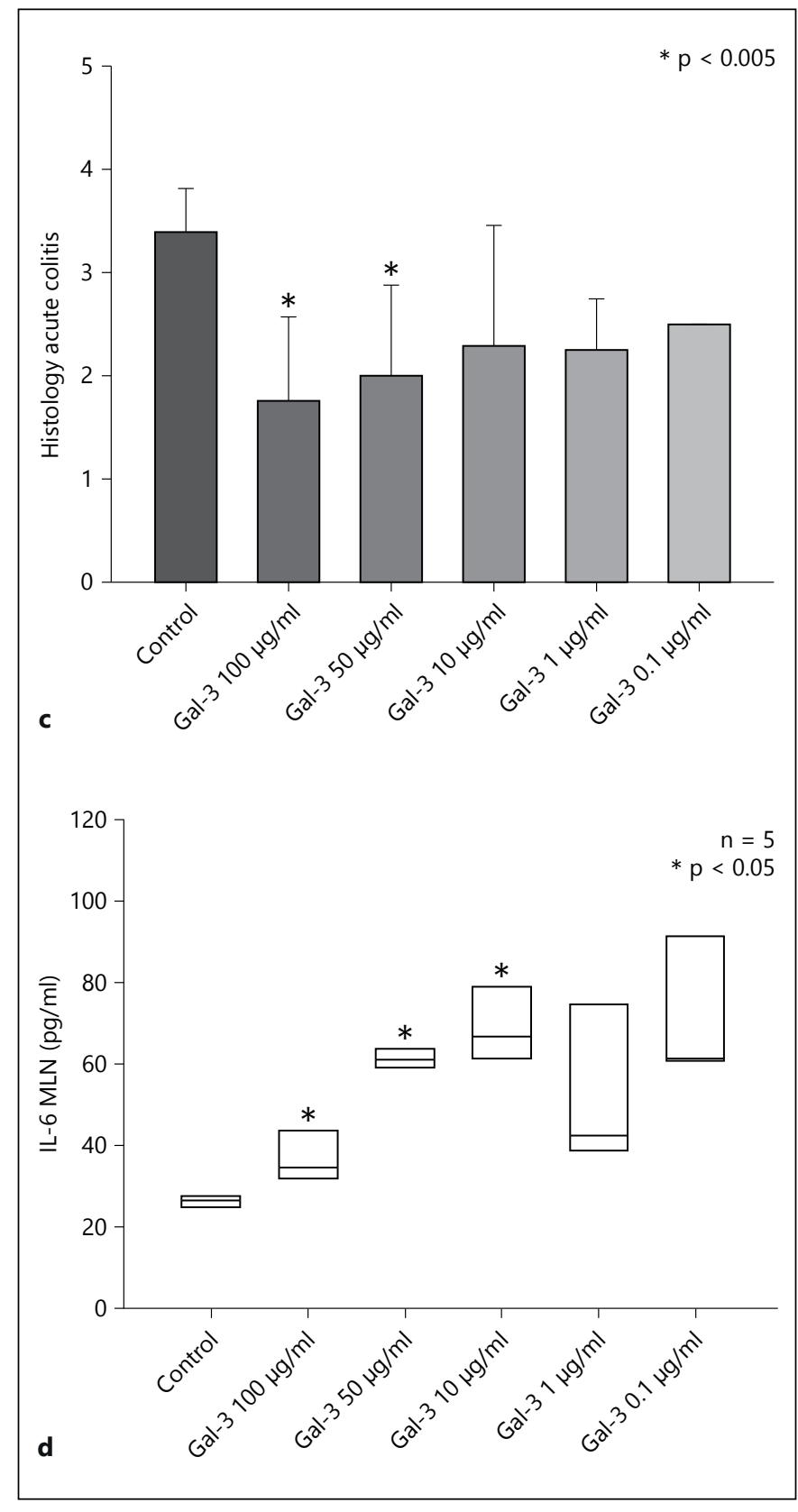

Fig. 2. Gal-3 reduces inflammation in acute colitis. c Histologic scores were evaluated at the end of the experiment for gal-3 treated mice and controls. d MLN were isolated and pooled from all groups and analysed for cytokine secretion. In the supernatant, IL-6 was increased in gal-3 treated mice.

$\mathrm{ml}, \mathrm{p}<0.001$ and gal-3 $0.1 \mathrm{~g} / \mathrm{ml}, \mathrm{p}<0.001$; fig. 2b). Histologic analysis demonstrated significantly less inflammation and less tissue damage in the gal-3 groups (fig. 2c). Gal-3-treated mice had a lower score of inflammation compared to controls reaching statistical significance

Gal-3 Modulates Experimental Colitis
$(100 \mu \mathrm{g} / \mathrm{ml}: 0.005 ; 50 \mu \mathrm{g} / \mathrm{ml}: 0.005)$. In contrast, MPO activity revealed only statistical significance in animals treated with gal-3 $0.1 \mu \mathrm{g} / \mathrm{ml}(\mathrm{p}<0.001)$, however, showing decreased levels in the treatment groups, but with no statistical significance (data not shown). To evaluate whether amelioration of intestinal inflammation in gal3-treated animals was accompanied by modulation of cytokine secretion, we compared cytokine production of MLN. Cytokine concentrations were measured in the supernatants of MLN pooled from controls and gal-3-treated mice. IL-6 secretion was inversely correlated to gal-3 concentration applied (fig. 2d). No significant differences were seen for the secretion of TNFa, IL-4 and IL-10 in controls and gal-3-treated animals (data not shown). In contrast to our in vitro findings, gal-3 was able to modulate inflammation and improve acute DSS colitis by reducing pro-inflammatory cytokine secretion and inflammation in the colon by modulating IL- 6 secretion. To further clarify the role of gal-3 in vivo, we investigated the impact of gal-3 in a chronic model of DSS-induced colitis.

\section{Gal-3 Improves Inflammation in Chronic \\ DSS-Induced Colitis in Mice}

In the chronic DSS colitis model, gal-3-treated mice displayed a concentration-dependent increase of colon length (with a statistical significance peak in the group receiving $10 \mu \mathrm{g} / \mathrm{ml}$ gal-3) indicating less inflammation in gal-3-treated animals (fig. 3a). MPO activity showed a clear decrease in the treatment groups not reaching statistical significance (data not shown). Histologic analysis revealed that DSS-induced inflammation was reduced in gal-3-treated animals compared to the control group in a concentration-dependent manner (fig. 3b; gal-3 $100 \mu \mathrm{g} /$ $\mathrm{ml}, \mathrm{p}<0.001$ and gal-3 $50 \mu \mathrm{g} / \mathrm{ml}, \mathrm{p}<0.001)$.

Pro-inflammatory cytokine secretion (IL-6) was suppressed in gal-3-treated mice in a concentration-dependent manner with lowest IL-6 levels in mice treated with highest gal-3 concentrations ( $100 \mu \mathrm{g} / \mathrm{ml}$; fig. $3 \mathrm{c})$. No significant differences were seen for the secretion of IL-10, IL-4 and TNFa (data not shown). Similar to the acute colitis model, gal-3 was also able to reduce inflammation and improve histology scores in a chronic model of DSS colitis.

\section{Discussion}

In this study, we were able to extend previous findings as our data show a crucial role for gal-3 in intestinal inflammation in vitro and in vivo. Our results show an in- 


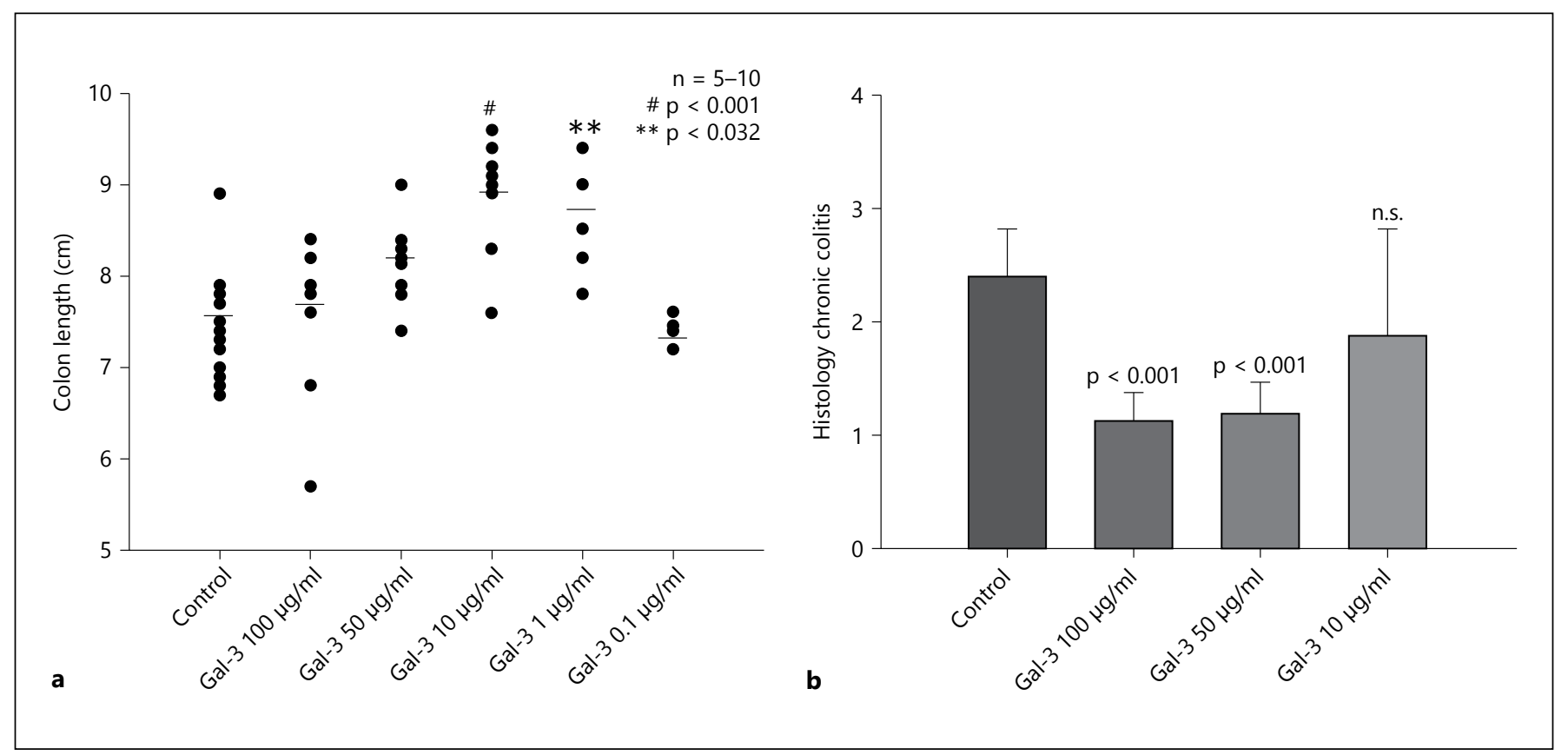

Fig. 3. Gal-3 reduces inflammation in chronic colitis. a Colonic length in chronic colitis. $\mathrm{n}=5-10$. $\mathbf{b}$ Histologic scores in mice with chronic colitis. c IL-6 secretion in the supernatants of MLN in chronic colitis.

duction of IL-8 secretion in intestinal fibroblasts by gal-3 in vitro. In vivo, in 2 animal models of intestinal inflammation, gal-3 has a protective and anti-inflammatory potential.

The induction of IL-8 secretion by gal-3 was increased upon co-incubation with TGF- $\beta 1$, while IL-4 and IL-10 were able to antagonize the gal-3 effect on IL-8 secretion.

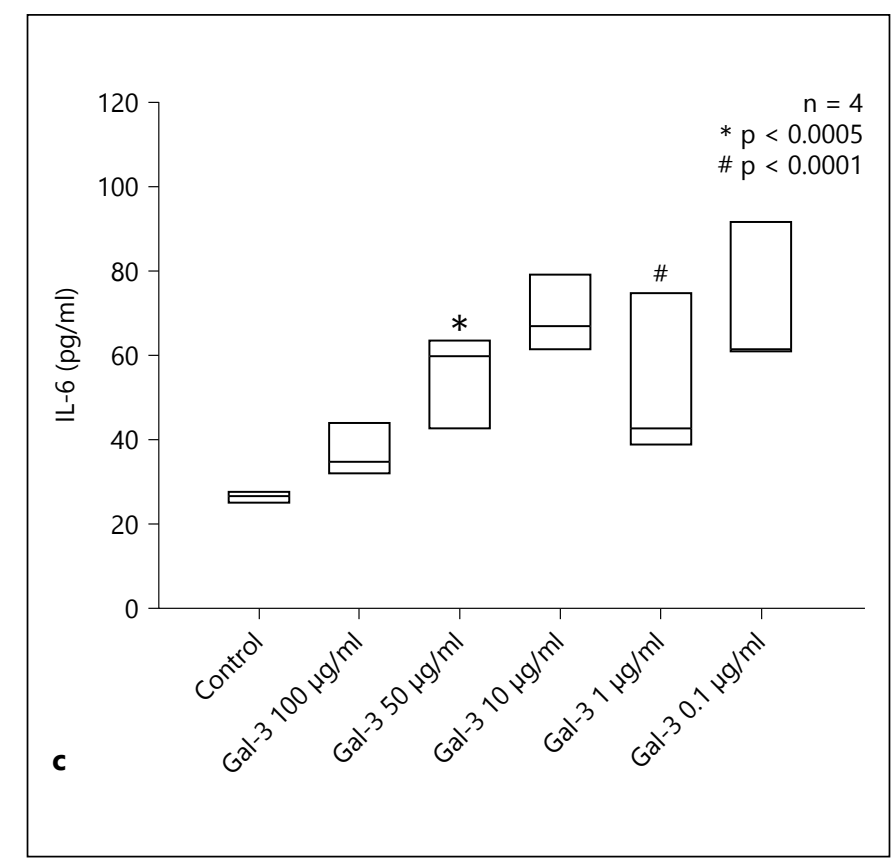

Using the DSS model of colitis, we were able to show a protective role of gal-3 in both acute and chronic inflammation. Significant reduced signs of inflammation were detected in the acute DSS model of colitis with increased colon length as a sign of lesser inflammation in gal3 -treated mice. Furthermore, gal-3 treatment improved colitis in the chronic DSS model. Gal-3 has extensively been studied in various kinds of inflammation with con- 
trary findings so far. In several studies, it was demonstrated that gal-3 might act as chemoattractant for dendritic cells or macrophages or can have an impact on the proliferation of activated T lymphocytes [26, 27]. Contrary to that, in fungal infections, gal-3 was shown to have a protective role [28]. In another model of infection, gal-3 was protective by a negative regulation of IL-17A responses through inhibition of IL-23/IL-17-axis cytokine production by dendritic cells [29]. Gal-3 was shown to have an inhibitory effect on monocyte migration and apoptosis [30]. However, infection with C. rodentium was only a minor effect in gal-3 null mice with delayed T-cell, macrophage and dendritic cells infiltration in the intestinal mucosa [31]. Our findings indicate a clear protective role of gal-3 with significant reduction of intestinal inflammation in a model of colitis.

Gal-3 seems to be protective in vivo by modulating IL-6 secretion. IL- 6 is involved in a different kind of inflammation and in the regulation of the humoral immune system. In a mouse model, IL- 6 has been shown to be a key player in TH1-mediated colitis while antagonizing IL-6 significantly improved colitis [32]. In humans, tocilizumab, a humanized anti-IL-6 receptor antibody, is already approved in the therapy of rheumatoid arthritis [33] and other autoimmune diseases [34]. A pilot study with tocilizumab in patients with $\mathrm{CD}$ has already indicated good tolerance, improved disease activity and effectiveness [35], and tocilizumab is expected to be approved in the therapy of CD with newer data in the near future. These data and our findings indicate a central role for IL-6 in inflammation in IBD while targeting or suppression of this interleukin results in improved colitis.

Our observation is in agreement with previous findings in humans showing that gal-3 was reduced in active colitis while being elevated in patients with no clinical manifestations confirming a protective role of gal-3 in intestinal inflammation [36]. In active CD, gal-3 expression is decreased in the inflamed epithelium [37]. Gal-3 expression could be reduced by TNF incubation in the colonic adenocarcinoma cell line HCT-8 [37]. TNF certainly is an important mediator of IBD-associated inflammation. However, in CLPF, we found a synergistic effect of TNF $a$ and gal-3. Other galectins such as gal-2 have been shown to induce T-cell apoptosis or modulate monocyte or macrophage functions $[30,38]$. In experimental colitis, gal-2 was shown to be able to improve acute and chronic colitis showing a clear role of galectins in inflammation and modulation of the immune system [39].

Gal-3 Modulates Experimental Colitis
A substantially higher percentage of sera from CD patients contained anti-gal-3 IgG autoantibodies than from those with ulcerative colitis and healthy controls. In $\mathrm{CD}$ patients, the titer of autoantibodies negatively correlated with disease activity [40]. This result was confirmed recently and gal-3 was shown to modulate T-cell function in IBDs [41]. Beside, in human dendritic cells, gal-3 is capable of inhibiting T-cell activation. Knock down of gal-3 in dendritic cells was followed by increased IFN $\gamma$ and reduced IL-10 expression [42]. Furthermore, gal-3 is able to influence TH17, a key player in tissue inflammation, by modulating cytokine secretion of dendritic cells [43]. Our study now provides evidence that gal-3 is able to modulate and improve colitis. Gal-3 showed a suppression of IL-6, indicating a TH1mediated suppression of inflammation in this model of colitis. These findings are in accordance with published data where gal-3 was capable to suppress T-cell responses [44].

To use a DSS model of colitis is widely accepted due to its simplicity and its similarity to human disease. However, a chemical induced model of colitis can never completely reflect the complexity of human disease, and the inherent differences between mice and humans need to be kept in mind. Therefore, further analysis of gal-3 in humans is warranted. Besides, the role and impact of gal-3 in other animal models of colitis need to be elucidated, since it is well known that they all use a different approach to inflammation (e.g. gene knockout, transgenic, chemical, adoptive transfer and spontaneous). These models will be helpful to further clarify the role of gal-3 in inflammation and to give a more detailed inside in the exact pathways used by gal- 3 and to confirm our findings of a more TH1-balanced modulation of inflammation [45].

In summary, we have demonstrated an in vivo model of acute and chronic colitis with a clear protective and key role of gal-3 and significant amelioration of intestinal inflammation. We could demonstrate that the gal-3 effect is mediated via modulation of IL- 6 .

Further investigations of gal-3 are warranted to underline the key role of gal-3 in inflammation and epithelial stabilization, to further characterize the subset of T-cells responsible for the protective effect of gal-3 and its potential role in IBDs.

\section{Disclosure Statement}

There are no conflicts of interests for all authors.

Digestion 2015;92:45-53

DOI: $10.1159 / 000431312$ 


\section{References}

1 Lippert E, Falk W, Bataille F, Kaehne T, Naumann M, Goeke M, Herfarth H, Schoelmerich J, Rogler G: Soluble galectin-3 is a strong, colonic epithelial-cell-derived, lamina propria fibroblast-stimulating factor. Gut 2007;56: 43-51.

2 Lippert E, Gunckel M, Brenmoehl J, Bataille F, Falk W, Scholmerich J, Obermeier F, Rogler G: Regulation of galectin-3 function in mucosal fibroblasts: potential role in mucosal inflammation. Clin Exp Immunol 2008; 152:285-297.

3 Barondes SH, Castronovo V, Cooper DN, Cummings RD, Drickamer K, Feizi T, Gitt MA, Hirabayashi J, Hughes C, Kasai K: Galectins: a family of animal beta-galactoside-binding lectins. Cell 1994;76:597-598.

4 Liu FT, Patterson RJ, Wang JL: Intracellular functions of galectins. Biochim Biophys Acta 2002;1572:263-273.

5 Seetharaman J, Kanigsberg A, Slaaby R, Leffler H, Barondes SH, Rini JM: X-ray crystal structure of the human galectin-3 carbohydrate recognition domain at 2.1-A resolution. J Biol Chem 1998;273:13047-13052.

6 Menon RP, Hughes RC: Determinants in the $\mathrm{N}$-terminal domains of galectin-3 for secretion by a novel pathway circumventing the endoplasmic reticulum-Golgi complex. Eur J Biochem 1999;264:569-576.

7 Henrick K, Bawumia S, Barboni EA, Mehul B, Hughes RC: Evidence for subsites in the galectins involved in sugar binding at the nonreducing end of the central galactose of oligosaccharide ligands: sequence analysis, homology modeling and mutagenesis studies of hamster galectin-3. Glycobiology 1998;8:45-57.

8 Kim K, Mayer EP, Nachtigal M: Galectin-3 expression in macrophages is signaled by Ras/ MAP kinase pathway and up-regulated by modified lipoproteins. Biochim Biophys Acta 2003; 1641:13-23.

9 Moutsatsos IK, Wade M, Schindler M, Wang JL: Endogenous lectins from cultured cells: nuclear localization of carbohydrate-binding protein 35 in proliferating 3T3 fibroblasts. Proc Natl Acad Sci U S A 1987;84:6452-6456.

10 Flotte TJ, Springer TA, Thorbecke GJ: Dendritic cell and macrophage staining by monoclonal antibodies in tissue sections and epidermal sheets. Am J Pathol 1983;111:112-124.

11 Davidson PJ, Davis MJ, Patterson RJ, Ripoche MA, Poirier F, Wang JL: Shuttling of galectin-3 between the nucleus and cytoplasm. Glycobiology 2002;12:329-337.

12 Mehul B, Hughes RC: Plasma membrane targetting, vesicular budding and release of galectin 3 from the cytoplasm of mammalian cells during secretion. J Cell Sci 1997;110(Pt 10):1169-1178.

13 Maeda N, Kawada N, Seki S, Arakawa T, Ikeda K, Iwao H, Okuyama H, Hirabayashi J, Kasai K, Yoshizato K: Stimulation of proliferation of rat hepatic stellate cells by galectin- 1 and galectin-3 through different intracellular signaling pathways. J Biol Chem 2003;278:18938-18944.
14 Sato S, Ouellet N, Pelletier I, Simard M, Rancourt A, Bergeron MG: Role of galectin-3 as an adhesion molecule for neutrophil extravasation during streptococcal pneumonia. J Immunol 2002;168:1813-1822.

15 Akahani S, Nangia-Makker P, Inohara $\mathrm{H}$, Kim HR, Raz A: Galectin-3: a novel antiapoptotic molecule with a functional BH1 (NWGR) domain of Bcl-2 family. Cancer Res 1997;57: 5272-5276.

16 Inohara H, Akahani S, Raz A: Galectin-3 stimulates cell proliferation. Exp Cell Res 1998;245:294-302.

17 Rubinstein N, Ilarregui JM, Toscano MA, Rabinovich GA: The role of galectins in the initiation, amplification and resolution of the inflammatory response. Tissue Antigens 2004; 64:1-12.

18 Liu SD, Lee S, La CA, Motran CC, Hahn BH, Miceli MC: Galectin-1-induced down-regulation of $\mathrm{T}$ lymphocyte activation protects $(\mathrm{NZB} \times \mathrm{NZW}) \mathrm{F} 1$ mice from lupus-like disease. Lupus 2011;20:473-484.

19 Motran CC, Molinder KM, Liu SD, Poirier F, Miceli MC: Galectin-1 functions as a Th2 cytokine that selectively induces Th1 apoptosis and promotes Th2 function. Eur J Immunol 2008;38:3015-3027.

20 Matarrese P, Tinari N, Semeraro ML, Natoli C, Iacobelli S, Malorni W: Galectin-3 overexpression protects from cell damage and death by influencing mitochondrial homeostasis. FEBS Lett 2000;473:311-315.

21 Dagher SF, Wang JL, Patterson RJ: Identification of galectin-3 as a factor in pre-mRNA splicing. Proc Natl Acad Sci U S A 1995;92: 1213-1217.

22 Hsu DK, Yang RY, Pan Z, Yu L, Salomon DR, Fung-Leung WP, Liu FT: Targeted disruption of the galectin-3 gene results in attenuated peritoneal inflammatory responses. Am J Pathol 2000;156:1073-1083.

23 Obermeier F, Kojouharoff G, Hans W, Schölmerich J, Gross V, Falk W: Interferongamma (IFN-gamma)- and tumour necrosis factor (TNF)-induced nitric oxide as toxic effector molecule in chronic dextran sulphate sodium (DSS)-induced colitis in mice. Clin Exp Immunol 1999;116:238-245.

24 Obermeier F, Strauch UG, Dunger N, Grunwald N, Rath HC, Herfarth H, Schölmerich J, Falk W: In vivo CpG DNA/toll-like receptor 9 interaction induces regulatory properties in CD4+CD62L+ T cells which prevent intestinal inflammation in the SCID transfer model of colitis. Gut 2005;54:1428-1436.

25 Hans W, Schölmerich J, Gross V, Falk W: The role of the resident intestinal flora in acute and chronic dextran sulfate sodium-induced colitis in mice. Eur J Gastroenterol Hepatol 2000;12:267-273.

26 Joo HG, Goedegebuure PS, Sadanaga N, Nagoshi M, von Bernstorff W, Eberlein TJ: Expression and function of galectin-3, a betagalactoside-binding protein in activated $\mathrm{T}$ lymphocytes. J Leukoc Biol 2001;69:555564.

27 Breuilh L, Vanhoutte F, Fontaine J, van Stijn CM, Tillie-Leblond I, Capron M, Faveeuw C, Jouault T, van Die I, Gosset P, Trottein F: Galectin-3 modulates immune and inflammatory responses during helminthic infection: impact of galectin-3 deficiency on the functions of dendritic cells. Infect Immun 2007;75:5148-5157.

28 Linden JR, De Paepe ME, Laforce-Nesbitt SS, Bliss JM: Galectin-3 plays an important role in protection against disseminated candidiasis. Med Mycol 2013;51:641-651.

29 Wu SY, Yu JS, Liu FT, Miaw SC, Wu-Hsieh BA: Galectin-3 negatively regulates dendritic cell production of IL-23/IL-17-axis cytokines in infection by Histoplasma capsulatum. J Immunol 2013;190:3427-3437.

30 Paclik D, Werner L, Guckelberger O, Wiedenmann B, Sturm A: Galectins distinctively regulate central monocyte and macrophage function. Cell Immunol 2011;271:97-103.

31 Curciarello R, Steele A, Cooper D, MacDonald TT, Kruidenier L, Kudo T: The role of galectin- 1 and galectin- 3 in the mucosal immune response to citrobacter rodentium infection. PLoS One 2014;9:e107933.

32 Yamamoto M, Yoshizaki K, Kishimoto T, Ito H: IL-6 is required for the development of Th1 cell-mediated murine colitis. J Immunol 2000;164:4878-4882.

33 Tanaka T, Narazaki M, Kishimoto T: Antiinterleukin-6 receptor antibody, tocilizumab, for the treatment of autoimmune diseases. FEBS Lett 2011;585:3699-3709.

34 Kang S, Tanaka T, Kishimoto T: Therapeutic uses of anti-interleukin-6 receptor antibody. Int Immunol 2015;27:21-29.

35 Ito H, Takazoe M, Fukuda Y, Hibi T, Kusugami K, Andoh A, Matsumoto T, Yamamura T, Azuma J, Nishimoto N, Yoshizaki K, Shimoyama T, Kishimoto T: A pilot randomized trial of a human anti-interleukin- 6 receptor monoclonal antibody in active Crohn's disease. Gastroenterology 2004;126:989-996; discussion 947.

36 Brazowski E, Dotan I, Tulchinsky H, Filip I, Eisenthal A: Galectin-3 expression in pouchitis in patients with ulcerative colitis who underwent ileal pouch-anal anastomosis (IPAA). Pathol Res Pract 2009;205:551-558.

37 Jensen-Jarolim E, Gscheidlinger R, Oberhuber G, Neuchrist C, Lucas T, Bises G, Radauer C, Willheim M, Scheiner O, Liu FT, Boltz-Nitulescu G: The constitutive expression of galectin-3 is downregulated in the intestinal epithelia of Crohn's disease patients, and tumour necrosis factor alpha decreases the level of galectin-3-specific mRNA in HCT-8 cells. Eur J Gastroenterol Hepatol 2002;14:145-152.

38 Sturm A, Lensch M, André S, Kaltner H, Wiedenmann B, Rosewicz S, Dignass AU, Gabius HJ: Human galectin-2: novel inducer of T cell apoptosis with distinct profile of caspase activation. J Immunol 2004;173:3825-3837. 
39 Paclik D, Berndt U, Guzy C, Dankof A, Danese S, Holzloehner P, Rosewicz S, Wiedenmann B, Wittig BM, Dignass AU, Sturm A: Galectin-2 induces apoptosis of lamina propria $\mathrm{T}$ lymphocytes and ameliorates acute and chronic experimental colitis in mice. J Mol Med (Berl) 2008;86:1395-1406.

40 Jensen-Jarolim E, Neumann C, Oberhuber G, Gscheidlinger R, Neuchrist C, Reinisch W, Zuberi RI, Penner E, Liu FT, Boltz-Nitulescu G: Anti-Galectin-3 IgG autoantibodies in patients with Crohn's disease characterized by means of phage display peptide libraries. J Clin Immunol 2001;21:348-356.
41 Müller S, Schaffer T, Flogerzi B, Fleetwood A, Weimann R, Schoepfer AM, Seibold F: Galectin-3 modulates T cell activity and is reduced in the inflamed intestinal epithelium in IBD. Inflamm Bowel Dis 2006;12:588597.

42 Mobergslien A, Sioud M: Galectin-1 and -3 gene silencing in immature and mature dendritic cells enhances $\mathrm{T}$ cell activation and interferon- $\gamma$ production. J Leukoc Biol 2012; 91:461-467.
43 Fermin Lee A, Chen HY, Wan L, Wu SY, Yu JS, Huang AC, Miaw SC, Hsu DK, Wu-Hsieh BA, Liu FT: Galectin-3 modulates Th17 responses by regulating dendritic cell cytokines. Am J Pathol 2013;183:1209-1222.

44 Tribulatti MV, Figini MG, Carabelli J, Cattaneo V, Campetella O: Redundant and antagonistic functions of galectin- $1,-3$, and -8 in the elicitation of $\mathrm{T}$ cell responses. J Immunol 2012;188:2991-2999.

45 Perše M, Cerar A: Dextran sodium sulphate colitis mouse model: traps and tricks. J Biomed Biotechnol 2012;2012:718617. 